\title{
Prevalence of Recurrent Hospital Admission in Children with Recurrent Wheezing in Babylon Province
}

\author{
Sura Falah ${ }^{1 *(D)}$, Saad Fawwaz Mukhlif ${ }^{2}$, Abeer Degan ${ }^{3}$ (D) \\ ${ }^{1}$ Department of Pediatrics, College of Medicine, University of Babylon, Hillah, Iraq; ${ }^{2}$ Department of Pediatrics, College of \\ Medicine, Al-Iraqia University, Baghdad, Iraq; ${ }^{3}$ Babylon Health Director, Babel Women's Children's Hospital, Babil, Iraq
}

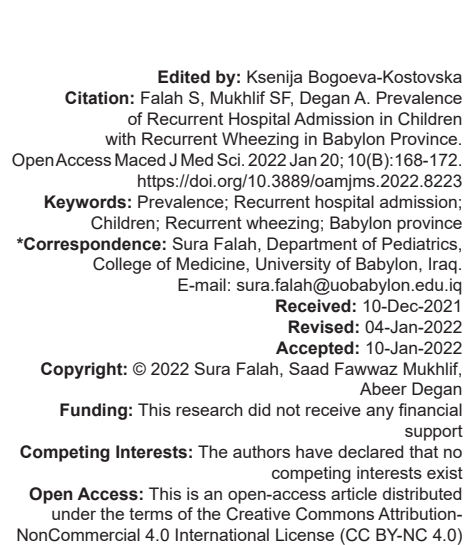

\section{Introduction}

Occurring of recurrent wheezing attacks signify a significant healthcare problem and considered one of the most common causes of emergency unit admission and hospitalizations. 1-3 children have at minimum one severe wheezing attack beforehand the age of 3 years [1]. Repeated wheezing can cause a chief financial problematic subsequent from the healthcare cost equivalent with the illness [2], [3]. Whereas the most public reasons of repeated wheezing is "asthma, gastroesophageal reflux disease (GER), foreign body aspiration, bronchopulmonary dysplasia (BPD), bronchiolitis obliterans, an immunodeficiency, primary ciliary dyskinesia, vocal cord dysfunction, cardiac and structural etiologies" [1]. Early life wheezing represents a common condition described by airways obstruction [4]. Wheezing is a common problem internationally, bronchiolitis and asthma being the most common causes of wheezing in preschool children [1], [5]. Infants with recurrent wheezing their parents always ask the doctor if their baby will develop asthma in future. Appropriate documentation of children at danger of developing asthma at school age may expect long-term consequences and recover management and protective method, but the opportunity to recognize these children at preschool age still inadequate [1]. While most of the patients predictable to recover and to be symptomfree at the age of 6 years and the bulk of them continue asymptomatic at the age of 11-16 years [6]. The aim of study is to determine the associations of recurrent hospital admissions in children with recurrent wheezing.

\section{Methods}

Cross-sectional descriptive study of 102 children with recurrent wheezy chest, the study done at Babylon Teaching Hospital for Children and Maternity, along a period from October 2020 to June 2021. Data collected from admitted patients with recurrent wheezing by direct interview with the patients' families. Patients were 6 months to 5 years old. Data collected including age, gender, place of living whether urban or rural, prematurity, no. of people at home, history of NCU admission, history of ICU admission, exclusive breast feeding for $1^{\text {st }} 6$ months, anemia, GERD, history of atopy, exposure to smoking, inhaler use, and CXR findings. Exclusion criteria include: 
1. Patients with chronic lung disease

2. Patients with cerebral palsy on nasogastric tube feeding

3. Patients less than 6 months of age

4. Patients with first time admission

Statistical analysis done by SPSS 22 frequency and percentage used for categorical data, mean, median and SD for continuous data. Chi-square used for assessed association between variables, $T$ test used for evaluation differences between mean and median of continues variables. $p \leq 0.05$ is considered significant.

\section{Results}

Cross-sectional study of 102 children with recurrent wheezing, (52.9\%) of them at age group, $1-3$ years old, (54\%) of children are males, $(51 \%)$ of babies in current study live in urban area, $(93.1 \%)$ of children have more than 3 persons live with them in house, (13.7\%) of babies are premature, also in current study show (48\%) of them have previous history of neonatal care unit (NCU) admission, this study show $(16.7 \%)$ of children have previous history of intensive care unit (ICU) admission, just $(35.3 \%)$ of them have history of breast feeding exclusive for 6 months, present study show that $(36.3 \%, 31.4 \%$, $42.2 \%, 30.4 \%, 33.3 \%, 9.8 \%$, and $5.9 \%$ ) of children have anemia, GERD, history of atopy, exposure to smoking, inhaler use, abnormal chest X-ray and congenital heart disease, respectively, as shown in Table 1.

Figure 1 shows the children distribution according to no. of hospitalization. (79.41\%) of children has 1-3 times admission in hospital.

There is significant association between the no. of hospitalization and history of ICU admission, $(71.4 \%)$ of children with more than 3 times admission to hospital have previous history of intensive care unit, also this study show (90\%) of children with more than 3 times admission to hospital present with GERD with significant association. Significant association of $(71.4 \%)$ of children with more than 3 times admission to hospital have previous history of exposure to smoking; the results of this study show $(61.9 \%)$ of babies that have no. of hospitalization more than 3 times inhaler use. $57.1 \%$ of children with more than 3 times admission to hospital show significant hyperinflation X-ray finding (Table 2).

\section{Discussion}

In the present study, most of children with recurrent wheezy chest are at age group 1-3 years
Table 1: Frequency and percentage of variables in the present study

\begin{tabular}{|c|c|c|}
\hline Variables & Frequency & Percentage \\
\hline \multicolumn{3}{|l|}{ Age (year) } \\
\hline$<1$ & 10 & 9.8 \\
\hline $1-3$ & 54 & 52.9 \\
\hline $3-5$ & 38 & 37.3 \\
\hline \multicolumn{3}{|l|}{ Gender } \\
\hline $\mathrm{F}$ & 46 & 45.1 \\
\hline M & 56 & 54.9 \\
\hline \multicolumn{3}{|l|}{ Place of living } \\
\hline Rural & 50 & 49.0 \\
\hline Urban & 52 & 51.0 \\
\hline \multicolumn{3}{|l|}{ No. of people in home } \\
\hline 3 and less & 7 & 6.9 \\
\hline$>3$ & 95 & 93.1 \\
\hline \multicolumn{3}{|l|}{ Prematurity } \\
\hline Yes & 14 & 13.7 \\
\hline No & 88 & 86.3 \\
\hline \multicolumn{3}{|l|}{ History of NCU admission } \\
\hline Yes & 49 & 48.0 \\
\hline No & 53 & 52.0 \\
\hline \multicolumn{3}{|l|}{ History of ICU admission } \\
\hline Yes & 17 & 16.7 \\
\hline No & 85 & 83.3 \\
\hline \multicolumn{3}{|c|}{ History of breast feeding exclusive for 6 months } \\
\hline Yes & 36 & 35.3 \\
\hline No & 66 & 64.7 \\
\hline \multicolumn{3}{|l|}{ Anemia } \\
\hline Yes & 37 & 36.3 \\
\hline No & 65 & 63.7 \\
\hline \multicolumn{3}{|l|}{ GERD } \\
\hline Yes & 32 & 31.4 \\
\hline No & 70 & 68.6 \\
\hline \multicolumn{3}{|l|}{ History of atopy } \\
\hline Yes & 43 & 42.2 \\
\hline No & 59 & 57.8 \\
\hline \multicolumn{3}{|l|}{ Exposure to smoking } \\
\hline Yes & 31 & 30.4 \\
\hline No & 71 & 69.6 \\
\hline \multicolumn{3}{|l|}{ Inhaler use } \\
\hline Yes & 34 & 33.3 \\
\hline No & 68 & 66.7 \\
\hline \multicolumn{3}{|l|}{ Chest $X$-ray finding } \\
\hline Hyperinflation & 21 & 20.6 \\
\hline Hyperinflation and pneumonia & 7 & 6.9 \\
\hline Normal & 71 & 69.6 \\
\hline Pneumonia & 3 & 2.9 \\
\hline \multicolumn{3}{|l|}{ Heart disease } \\
\hline No & 96 & 94.1 \\
\hline PDA & 1 & 1.0 \\
\hline Small ASD & 2 & 2.0 \\
\hline Small PDA & 1 & 1.0 \\
\hline Small VSD & 2 & 2.0 \\
\hline
\end{tabular}

old, and most of them were boys live in urban areas this supported by studies have stated that boys have high risk of early insistent wheezing and allergic sensitization and most of babies at age 14 months [1], [5], [7]. Furthermore, Sebnem et al.

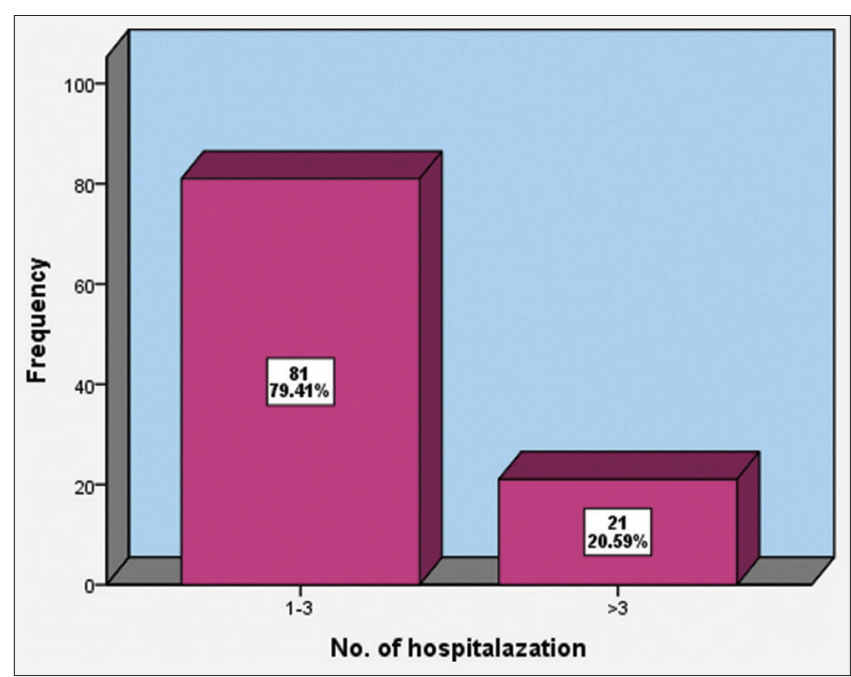

Figure 1: Children distribution according to no. of hospitalization 
supported current results that no. of people live with children are more than 4 [1]. The present study reveal that $79 \%$ of patients admitted one to 3 times to hospital due to recurrent wheezing and shortness of breath this results also compatible with results done by Sebnem et al. that show no. of admission to hospital are 2 [1]. In the present study there is no significant association between (weight, age, gender and living place, prematurity) of children and no. of recurrent admission to hospital, this is agreed with other results show no significant association [1], [8]. Breastfeeding defends against respiratory tract

Table 2: Association between variables in current study and no. of hospitalization

\begin{tabular}{|c|c|c|c|}
\hline \multirow[t]{2}{*}{ Variables } & \multicolumn{2}{|c|}{ No. of hospitalization } & \multirow[t]{2}{*}{$\mathrm{p}$-value } \\
\hline & $1-3$ & $>3$ & \\
\hline \multicolumn{4}{|l|}{ Weight (kg) } \\
\hline Mean \pm SD & $12.97 \pm 3.2$ & $14.37 \pm 4$ & 0.096 \\
\hline \multicolumn{4}{|l|}{ Age (years) } \\
\hline$<1$ & $10(12.3 \%)$ & $0(0 \%)$ & \\
\hline $1-3$ & $43(53.1 \%)$ & $11(52.4 \%)$ & 0.19 \\
\hline $3-5$ & $28(34.6 \%)$ & $10(47.6 \%)$ & \\
\hline Total & $81(100 \%)$ & $21(100 \%)$ & \\
\hline \multicolumn{4}{|l|}{ Gender } \\
\hline Female & $37(45.7 \%)$ & $9(42.9 \%)$ & \\
\hline Male & $44(54.3 \%)$ & $12(57.1 \%)$ & 1.000 \\
\hline Total & $81(100 \%)$ & $21(100 \%)$ & \\
\hline \multicolumn{4}{|l|}{ Place of living } \\
\hline Rural & $36(44.4 \%)$ & $14(66.7 \%)$ & \\
\hline Urban & $45(55.6 \%)$ & $7(33.3 \%)$ & 0.088 \\
\hline Total & $81(100 \%)$ & $21(100 \%)$ & \\
\hline \multicolumn{4}{|l|}{ Prematurity } \\
\hline Yes & $9(11.1 \%)$ & $5(23.8 \%)$ & 0.16 \\
\hline No & $72(88.9 \%)$ & $16(76.2 \%)$ & \\
\hline Total & $81(100 \%)$ & $21(100 \%)$ & \\
\hline \multicolumn{4}{|l|}{ History of NCU admission } \\
\hline Yes & $42(51.9 \%)$ & $7(33.3 \%)$ & 0.15 \\
\hline No & $39(48.1 \%)$ & $14(66.7 \%)$ & \\
\hline Total & $81(100 \%)$ & $21(100 \%)$ & \\
\hline \multicolumn{4}{|l|}{ History of ICU admission } \\
\hline Yes & $2(2.5 \%)$ & $15(71.4 \%)$ & \\
\hline No & $79(97.5 \%)$ & $6(28.6 \%)$ & 0.0001 \\
\hline Total & $81(100 \%)$ & $21(100 \%)$ & \\
\hline \multicolumn{4}{|l|}{ Breast feeding } \\
\hline Yes & $29(35.8 \%)$ & $7(33.3 \%)$ & \\
\hline No & $52(46.2 \%)$ & $14(66.7 \%)$ & 1.000 \\
\hline Total & $81(100 \%)$ & $21(100 \%)$ & \\
\hline \multicolumn{4}{|l|}{ Anemia } \\
\hline Yes & $30(37 \%)$ & $7(33.3 \%)$ & \\
\hline No & $51(63 \%)$ & $14(66.7 \%)$ & 0.8 \\
\hline Total & $81(100 \%)$ & $21(100 \%)$ & \\
\hline GERD & & & \\
\hline Yes & $13(16 \%)$ & $19(90 \%)$ & \\
\hline No & $68(84 \%)$ & $2(9.5 \%)$ & 0.0001 \\
\hline Total & $81(100 \%)$ & $21(100 \%)$ & \\
\hline History of atopy & & & \\
\hline Yes & $36(44.4 \%)$ & $7(33.3 \%)$ & \\
\hline No & $45(55.6 \%)$ & $14(66.7 \%)$ & 0.46 \\
\hline Total & $81(100 \%)$ & $21(100 \%)$ & \\
\hline Exposure to smoking & & & \\
\hline Yes & $16(19.8 \%)$ & $15(71.4 \%)$ & \\
\hline No & $65(80.2 \%)$ & $6(28.6 \%)$ & 0.0001 \\
\hline Total & $81(100 \%)$ & $21(100 \%)$ & \\
\hline Inhaler use & & & \\
\hline Yes & $21(25.9 \%)$ & $13(61.9 \%)$ & \\
\hline No & $60(74.1 \%)$ & $8(38.1 \%)$ & 0.004 \\
\hline Total & $81(100 \%)$ & $21(100 \%)$ & \\
\hline Chest X-ray & & & \\
\hline Hyperinflation & $9(11.1 \%)$ & $12(57.1 \%)$ & \\
\hline Hyperinflation and pneumonia & $1(1.2 \%)$ & $6(28.6 \%)$ & 0.0001 \\
\hline Normal & $69(85.2 \%)$ & $2(9.5 \%)$ & \\
\hline Pneumonia & $2(2.5 \%)$ & $1(4.8 \%)$ & \\
\hline Total & $81(100 \%)$ & $21(100 \%)$ & \\
\hline No. of people & & & \\
\hline 3 and less & $7(8.6 \%)$ & $0(0 \%)$ & \\
\hline$>3$ & $74(91.4 \%)$ & $21(100 \%)$ & 0.34 \\
\hline Total & $81(100 \%)$ & $21(100 \%)$ & \\
\hline Heart disease & & & \\
\hline No & $76(93.8 \%)$ & $20(95.2 \%)$ & \\
\hline PDA & $0(0 \%)$ & $1(4.8 \%)$ & \\
\hline Small ASD & $2(2.5 \%)$ & $0(0 \%)$ & 0.27 \\
\hline Small PDA & $1(1.2 \%)$ & $0(0 \%)$ & \\
\hline Small VSD & $2(2.5 \%)$ & $0(0 \%)$ & \\
\hline Total & $81(100 \%)$ & $21(100 \%)$ & \\
\hline
\end{tabular}

infections during early life. Whereas there are systematic studies significant, that breastfeeding act as defense against wheezing, while other studies have not seen any association. In the present study, we unsuccessful to recognize any association between breastfeeding and repeated wheezing, due to little sample size. This results agreed with other results have the same value [9], [10]. Smoking has a strong relationship with repeated wheezing [11], [12]. In the present study, we find significant association between recurrent hospitalization of babies and exposure to smoking $(71 \%)$ of children with more than 3 times admission have exposure to smoking. British Cohort Study supported our results show a strong association between maternal smoking and the incidence of wheezing during early children's life [13]. During prenatal period, maternal smoking has effects on the fetus lung function and increases the danger of wheezing at 3 years of life [14]. In the present study, there is no association between recurrent hospitalization and presence of anemia in babies, other results show association between anemia and lower respiratory infections. Iron deficiency anemia disturbs the immune response and alterations the metabolism of pathogens. A low tissue hemoglobin level weakens tissue oxygenation and signifies a danger for respiratory infections in children [15], [16]. These differences due to small sample size taken in our results. In the present study, there is highly significant association between more than 3 times admission and GERD considered as risk factors of recurrent hospitalization due to recurrent wheezing 19 babies more than 3 times admission have history of GERD, this is supported by many studies that show significant association. A study discovering the association between the reappearance of respiratory symptoms and GER, observed GER in $35 \%$ of the patients. An obvious lowering in wheezing attack observed 3-6 months after anti-reflux treatment. Patra et al. demonstration that $42 \%$ of the wheezy patients under the age of 1 year had positive GER investigations. They description that GER is a significant cause of recurring wheezing in patients under 2 years of age and commend GER examinations in patients with severe occurrences having an onset under the age of 1 year [17], [18]. In current study, we find significant association between recurrent hospitalization of babies and inhaler uses, salbutamol syrup remnants in use for the management of wheezing and babies that have more than 3 times admission to hospital associated with inhaler used, this is agreed with other studies that show the same association [1], [19]. In present study, there is no significant association between recurrent hospitalization of babies and babies' history of neonatal care unit admission and cardiac disease, but significant association between recurrent hospitalization of babies and babies' history of intensive care unit admission, $(71 \%)$ of babies with more than 3 times admission have positive history of 
intensive care unit admission, this is similar to study done in UK also show the same association [20]. Furthermore, in present study, most children frequently admitted to hospital due to recurrent wheezing have hyperinflation finding in X-ray (57\%), this agreed with Halaby et al. that show the babies with recurrent wheezing that frequently admitted to hospital is due to bronchitis or asthma this appears as hyperinflation on chest X-ray [21].

\section{Conclusion}

One to three years old children is the most common age they have recurrent wheezing, most of them are males and they live in urban area, most children with recurrent wheezy chest have more than 3 times hospitalization, most babies with recurrent admissions due to recurrent wheezing attack have previous history of ICU admission, have GERD and have high exposure to smoking. Due to shortness of breath, children who use inhaler have more times hospitalization, with hyperinflation X-ray finding.

\section{References}

1. Ozdogan S, Tabakci B, Demirel AS, Atli B, Besli GE, Kose G. The evaluation of risk factors for recurrent hospitalizations resulting from wheezing attacks in preschool children. Ital J Pediatr. 2015;41(1):1-7. http://dx.doi.org/10.1186/s13052-015-0201-z PMid:26577276

2. de Vries E, van Hout RW. Respiratory symptoms in postinfancy children. A Dutch pediatric cohort study. Front Pediatr. 2020;8:583630. http://dx.doi.org/10.3389/fped.2020.583630 PMid:33392115

3. Zar HJ, Ferkol TW. The global burden of respiratory diseaseimpact on child health. Pediatr Pulmonol. 2014;49(5):430-4. http://dx.doi.org/10.1002/ppul.23030

PMid:24610581

4. Ducharme FM, Tse SM, Chauhan B. Diagnosis, management, and prognosis of preschool wheeze. Lancet (London, England). 2014;383(9928):1593-604. http://dx.doi.org/10.1016/ S0140-6736(14)60615-2

PMid:24792856

5. Garcia-Marcos L, Mallol J, Solé D, Brand PL. International study of wheezing in infants: risk factors in affluent and non-affluent countries during the first year of life. Pediatr Allergy Immunol. 2010;21(5):878-88. http://dx.doi. org/10.1111/j.1399-3038.2010.01035.x

PMid:20444158

6. Soh JE, Kim KM, Kwon JW, Kim HY, Seo JH, Bin KH, et al. Recurrent wheeze and its relationship with lung function and airway inflammation in preschool children: A cross-sectional study in South Korea. BMJ Open. 2017;7(10):e018010. http:// dx.doi.org/10.1136/bmjopen-2017-018010

PMid:28993393
7. Melén E, Kere J, Pershagen G, Svartengren M, Wickman M. Influence of male sex and parental allergic disease on childhood wheezing:Roleofinteractions. ClinExpAllergy.2004;34(6):839-44. http://dx.doi.org/10.1111/j.1365-2222.2004.01957.x PMid:15196268

8. Wright AL. Epidemiology of asthma and recurrent wheeze in childhood. Clin Rev Allergy Immunol. 2002;22(1):33-44. http:// dx.doi.org/10.1007/s12016-002-0004-z

PMid:11803801

9. Kramer MS, Matush L, Vanilovich I, Platt RW, Bogdanovich N, Sevkovskaya $Z$, et al. Effects of prolonged and exclusive breastfeeding on child height, weight, adiposity, and blood pressure at age $6.5 \mathrm{y}$ : Evidence from a large randomized trial. Am J Clin Nutr. 2007;86(6):1717-21. http://dx.doi.org/10.1093/ ajcn/86.5.1717

PMid: 18065591

10. Martin RM, Kramer MS, Patel R, Rifas-Shiman SL, Thompson J, Yang $\mathrm{S}$, et al. Effects of promoting long-term, exclusive breastfeeding on adolescent adiposity, blood pressure, and growth trajectories: A secondary analysis of a randomized clinical trial. JAMA Pediatr. 2017;171(7):e170698. http://dx.doi. org/10.1001/jamapediatrics.2017.0698

PMid:28459932

11. Murrison LB, Brandt EB, Myers JB, Khurana Hershey GK Environmental exposures and mechanisms in allergy and asthma development. J Clin Invest. 2019;129(4):1504-15. https://doi.org/10.1172/JCl124612

PMid:30741719

12. Gilmour MI, Jaakkola MS, London SJ, Nel AE, Rogers CA. How exposure to environmental tobacco smoke, outdoor air pollutants, and increased pollen burdens influences the incidence of asthma. Environ Health Perspect. 2006;114(4):627-33. https:// doi.org/10.1289/ehp.8380

PMid:16581557

13. Silvestri M, Franchi S, Pistorio A, Petecchia L, Rusconi F. Smoke exposure, wheezing, and asthma development: A systematic review and meta-analysis in unselected birth cohorts. Pediatr Pulmonol. 2015;50(4):353-62. https://doi.org/10.1002/ppul.23037 PMid:24648197

14. Zhuge Y, Qian H, Zheng X, Huang C, Zhang Y, Li B, et al. Effects of parental smoking and indoor tobacco smoke exposure on respiratory outcomes in children. Sci Rep. 2020;10(1):4311 https://doi.org/10.1038/s41598-020-60700-4 PMid:32152374

15. Ramakrishnan K, Harish PS. Hemoglobin level as a risk factor for lower respiratory tract infections. Indian J Pediatr. 2006;73(10):881-3. PMid: 17090898

16. Hussain SQ, Ashraf M, Wani JG, Ahmed J. Low hemoglobin level a risk factor for acute lower respiratory tract infections (ALRTI) in children. J Clin Diagn Res. 2014;8(4):PC01. https:// doi.org/10.7860/JCDR/2014/8387.4268 PMid:24959486

17. Thakkar $\mathrm{K}$, Boatright $\mathrm{RO}$, Gilger MA, El-Serag HB Gastroesophageal reflux and asthma in children: A systematic review. Pediatrics. 2010;125(4):e925-30. https://doi. org/10.1542/peds.2009-2382

PMid:20351005

18. Patra S, Singh V, Chandra J, Kumar P, Tripathi M. Gastroesophageal reflux in early childhood wheezers. Pediatr Pulmonol. 2011;46(3):272-7. https://doi.org/10.1002/ppul.21363 PMid:20967836

19. Ye X, Gutierrez B, Zarotsky V, Nelson M, Blanchette CM Appropriate use of inhaled corticosteroid and long-acting beta(2)adrenergic agonist combination therapy among asthma patients 
in a US commercially insured population. Curr Med Res Opin. 2009;25(9):2251-8. https://doi.org/10.1185/03007990903155915 PMid:19622006

20. Ghazaly M, Nadel S. Characteristics of children admitted to intensive care with acute bronchiolitis. Eur J Pediatr. 2018;177(6):913-20. https://doi.org/10.1007/s00431-018-3138-6
PMid:29654399

21. Halaby C, Feuerman M, Barlev D, Pirzada M. Chest radiography in supporting the diagnosis of asthma in children with persistent cough. Postgrad Med. 2014;126(2):117-22. https://doi. org/10.3810/pgm.2014.03.2747

PMid:24685975 